https://dx.doi.org/10.4314/ijs.v19i2.6

Ife Journal of Science vol. 19, no. 2 (2017)

\title{
INTEGRATED GEOPHYSICAL AND HYDROCHEMICAL INVESTIGATIONS OF SUBSOIL AND GROUNDWATER POLLUTION AROUND THREE CASSAVA PROCESSING FACTORIES AT IRETI-AYO COMMUNITY, ILESHA, SOUTHWESTERN NIGERIA
}

\author{
Adigun, E. O. and Olorunfemi, M. O. \\ Dept. of Geology, Obafemi Awolowo University, Ile-Ife, Nigeria \\ *Corresponding author: tayoradigun@gmail.com \\ (Received: 10th September, 2017; Accepted: 18th September, 2017)
}

ABSTRACT

\begin{abstract}
Integrated geophysical and hydrochemical investigations were carried out within the vicinity of three cassava processing factory sites at Ireti-Ayo Community in Ilesha, Southwestern Nigeria. This was with a view to assessing the impact of the cassava effluent on the soil/subsoil and the groundwater quality within the study area. Fourteen Vertical Electrical Soundings (VES) data were acquired using the Schlumberger array while 2-D Dipole-Dipole data were acquired along six traverses. Hydrochemical analysis was also carried out on the cassava effluent and well water samples for cyanide, pH, TDS, electrical conductivity, acidity, alkalinity, cations and anions concentrations. The VES data were quantitatively interpreted using the partial curve matching and 1-D computer assisted forward modeling while the 2-D Dipole-Dipole data were inverted into 2-D resistivity structures. The elemental concentrations were compared with the WHO (2006) standard for potable water. The VES derived geoelectric sections identified four lithological layers which comprised the topsoil $(8-638 \Omega \mathrm{m})$, laterite $(278-2468 \Omega \mathrm{m})$, weathered basement $(32-1004 \Omega \mathrm{m})$ and fresh basement $(536-20883 \Omega \mathrm{m})$. The thin topsoil was underlain by a relatively thick lateritic layer (up to $12.2 \mathrm{~m}$ ). The sampled cassava effluent resistivity was6.5 $\Omega \mathrm{m}$. The topsoil and part of the underlying laterite at and around the vicinity of the three cassava processing factory sites had relatively low resistivity values $(6-112 \Omega \mathrm{m})$ diagnostic of cassava effluent impacted zones. The pollution plumes depth extents were estimated to range from 2.5 to $5 \mathrm{~m}$ with a migration rate of about $0.24 \mathrm{~m}$ /year. The migration of the pollution plume may have been inhibited by the relatively thick column of laterite underlying the topsoil. Cyanide was detected $(0.8 \mathrm{mg} / \mathrm{L})$ in the cassava effluent, but not in the analysed well water samples. For both the upstream and downstream well water samples respectively, the physicochemical parameters were all within the WHO permissible levels. The study concluded that the groundwater in the vicinity of the factory sites investigated had not been polluted by the cassava effluent. However, the subsoils within the sites have been polluted to depth of up to $5 \mathrm{~m}$.
\end{abstract}

Keywords: Geophysical Investigation, Hydrochemical Analysis, Cassava Effluents, Groundwater Quality.

\section{INTRODUCTION}

Water is an indispensable requirement that sustains life. Most human activities such as agriculture, industries and domestic needs depend upon the availability of water resources (Awomeso et al., 2010). Water can exist both as surface and groundwater. The groundwater reserve of the world is about $5.0 \times 10^{24}$ litres and thus constitutes a significant proportion of the earth's water resources (Buchanan, 1983). However, the quality of groundwater is as important as its enormous quantity (Todd, 1980). The quality of drinking water is determined by its physical, chemical and microbiological characteristics. (Olarewaju et al., 1997). In Nigeria, only $48 \%$ of urban dwellers and $39 \%$ of rural dwellers have access to potable water (Federal Republic of Nigeria, 2002). Wastes generated from agricultural farmland and industries have contributed immensely to water pollution when contaminants percolate into the groundwater (Forster et al., 1998). Drinking contaminated water could result into a variety of water borne diseases such as Diarrhoea, Cholera, Dysentery and Typhoid. Geophysical methods involving Vertical Electrical Sounding (VES) and 2D electrical resistivity imaging are relevant in the mapping of subsurface lithology and pollution plume (Amidu and Olayinka, 2006; Atakpo et al., 2011; Bayowa et al., 2012 and Orakwe, 2016). Hydrochemical analysis involving the determination of physicochemical parameters of water samples is also essential in area(s) of suspected groundwater contamination (Olarewaju et al., 1997; Akoteyon et al., 2011). The Ireti-Ayo Community, in Ilesha SW Nigeria, is noted for cassava processing. The community has three (3) cassava processing units where effluents are directly discharged within the 
immediate vicinities. Disposal of cassava liquid waste to the environment directly pollute the soil/subsoil while groundwater may be polluted indirectly through infiltration. This study intends to investigate the impact of the effluents on the soil/subsoil and the groundwater.

\section{Description of the Study Area}

The study area is located at Ireti-Ayo, in Ilesha, Osun State, SW Nigeria. It lies between Northings 845200 and $846000 \mathrm{mN}$ and Eastings 694300and $694900 \mathrm{mE}$ using the Universal Traverse Mercator (UTM) Zone 31 coordinate system (Fig. 1), with a total area of about $540 \mathrm{~km}^{2}$. The the area is drained by some seasonal streams flowing in the Northwest-Southeast direction (Fig. 2). It falls within the tropical climatic region with an average daily temperature that varies between about $20^{\circ} \mathrm{C}$ and $35^{\circ} \mathrm{C}$ and an annual rainfall of about $1600 \mathrm{~mm}$ within the raining season (OSSADEP, 1997). The vegetation is the tropical rain forest type. The area is entirely underlain by Amphibolite Schist (Fig. 3) and it is located on a relatively flat to gently undulating terrain with elevation that ranges from $374 \mathrm{~m}$ to $387 \mathrm{~m}$.

\section{MATERIALS AND METHODOLOGY}

The GARMIN 12 channel personal navigator GPS unit was used to acquire the coordinates of relevant features and these were used to generate the base map of the study area (Fig. 4). The base map was used to establish geophysical traverses and points for water sample collection. The investigation involved integration of geophysical and hydrochemical methods.

\section{Geophysical Investigation}

The geophysical investigation involved the electrical resistivity method which employed the 2-D Dipole-Dipole imaging and 1-D Vertical Electrical Sounding (VES) techniques. The 2-D Dipole-Dipole imaging technique was adopted along established geophysical traverses at the three cassava processing factory sites. Five meter $(5 \mathrm{~m})$ dipole length and dipole expansion factor (n) varying from 1 to 5 were adopted for the $2-\mathrm{D}$ data acquisition. The Dipole-Dipole data were inverted into 2-D resistivity structures (images) using the DIPRO for window Software. The resulting 2-D resistivity images were used to delineate pollution plumes and also used to constrain the locations of the VES points along each traverse.

The 1-D Vertical Electrical Sounding (VES) data were acquired using the Schlumberger array. The current electrode spacing $(\mathrm{AB} / 2)$ was varied from 1 to $100 \mathrm{~m}$. The acquired data were plotted as VES curves and interpreted quantitatively using the method of partial curve matching and computer assisted 1-D forward modeling with the WinResist software. The VES interpretation results were used to generate geoelectric sections along the established traverses.

\section{Hydrochemical Analysis}

The pH, Electric Conductivity, Total Dissolved Solids (TDS) and Temperature of cassava effluent sample collected at the oldest cassava processing unit (Unit 3 which had been active for over 20 years) and well water samples collected at both the upstream and downstream sides of the processing site were measured insitu at the oldest cassava processing factor site. The samples were labeled appropriately and immediately sent to the laboratory to test for the concentration of Cyanide, $\mathrm{Ca}^{2+}, \mathrm{Mg}^{2+}, \mathrm{Na}^{+}, \mathrm{K}^{+}, \mathrm{Fe}^{2+}, \mathrm{Cl}, \mathrm{NO}_{3}, \mathrm{SO}_{4}^{2-}$ and $\mathrm{PO}_{4}{ }^{3}$.The results obtained from the hydrochemical analyses were compared with WHO drinking water standard so as to establish the groundwater quality.

\section{RESULTS AND DISCUSSION VES Type Curves}

Three (3) VES type curves including the $\mathrm{KH}$, $\mathrm{HKH}$ and KHKH type (Table 1) were identified from the fourteen (14) Vertical Electrical Sounding (VES) stations that were occupied along six (6) established geophysical traverses within the study area. The KH type curve is the dominant type curve. 


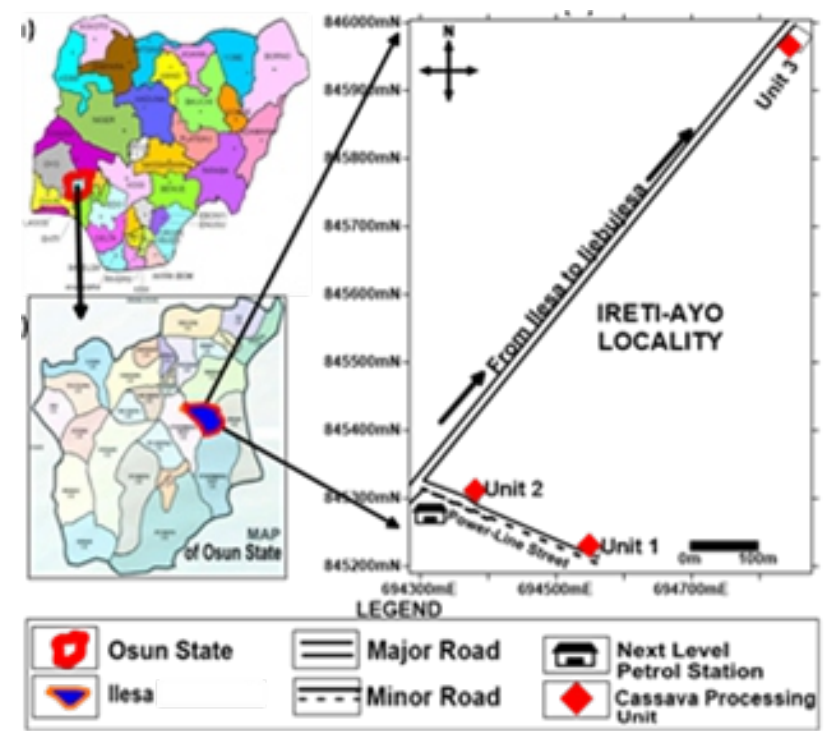

Fig. 1: Map of Osun State Showing the Three Cassava Processing Factories within the Ire-Ayo Study Area in Ilesha Town.

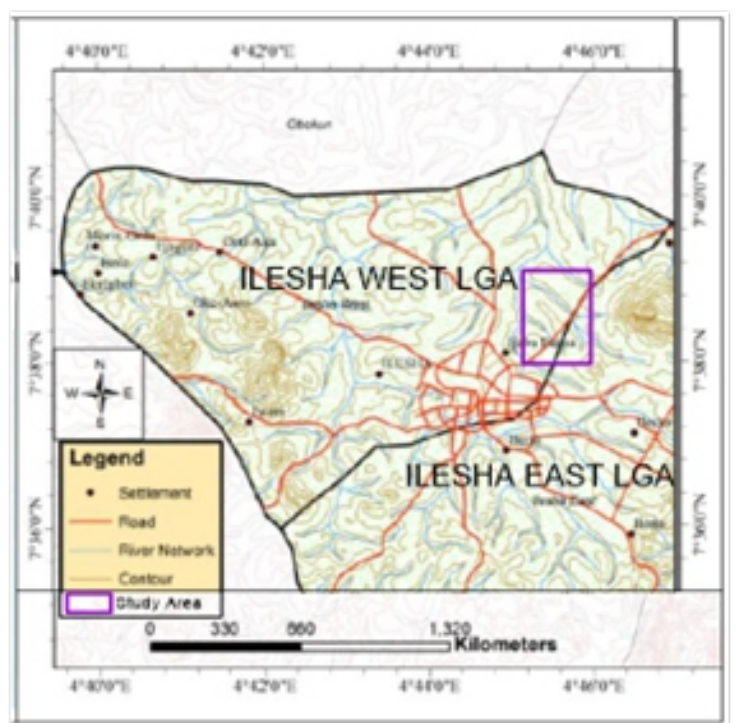

Fig. 2: Topographic Map of Ilesha Area showing the Study Area (Adapted from Felix and Olusola, 2016)

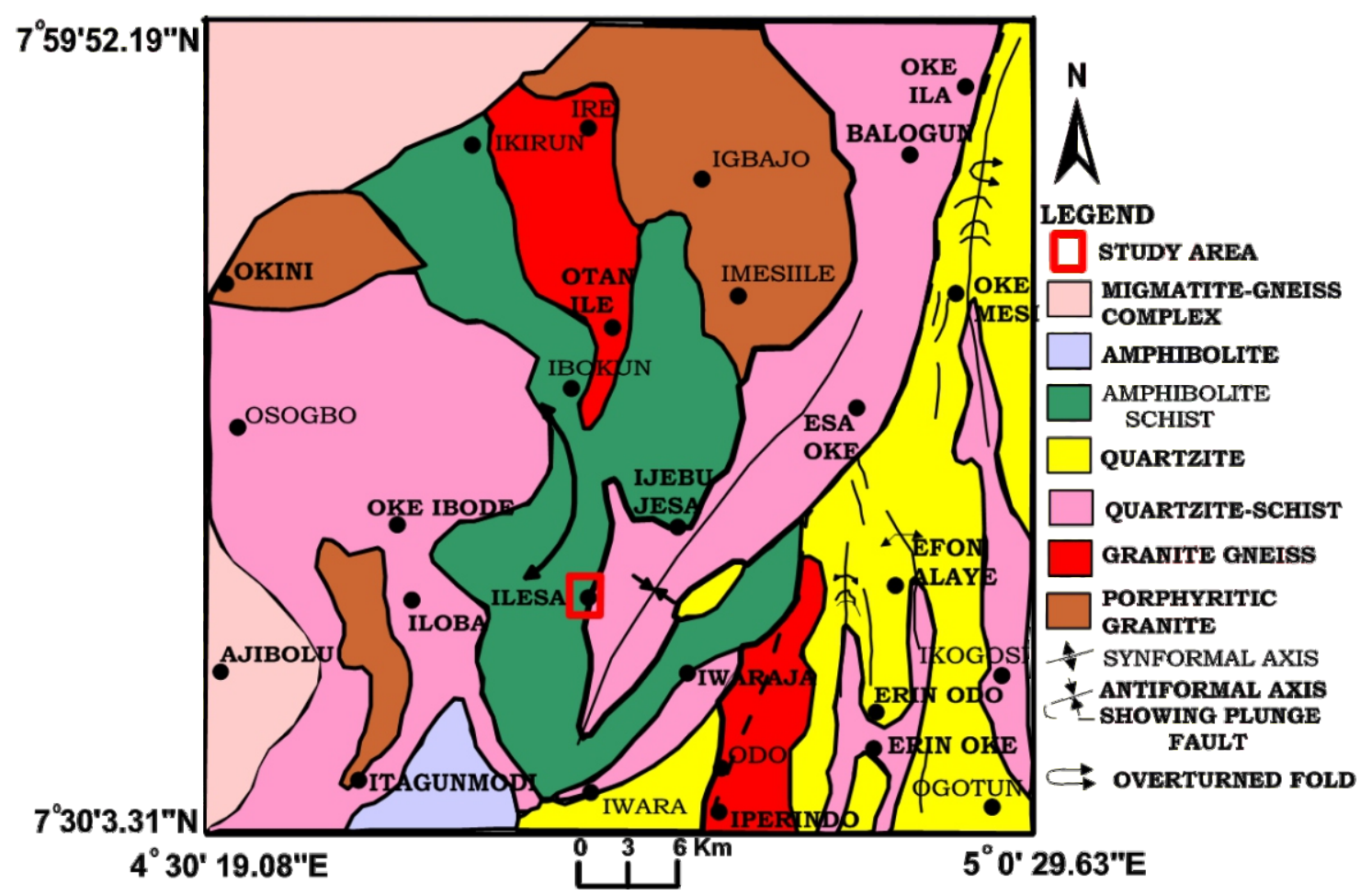

Fig. 3: Geological Map of Area around Ilesha Showing the Study Area (Adapted from Odeyemi, 1993) 


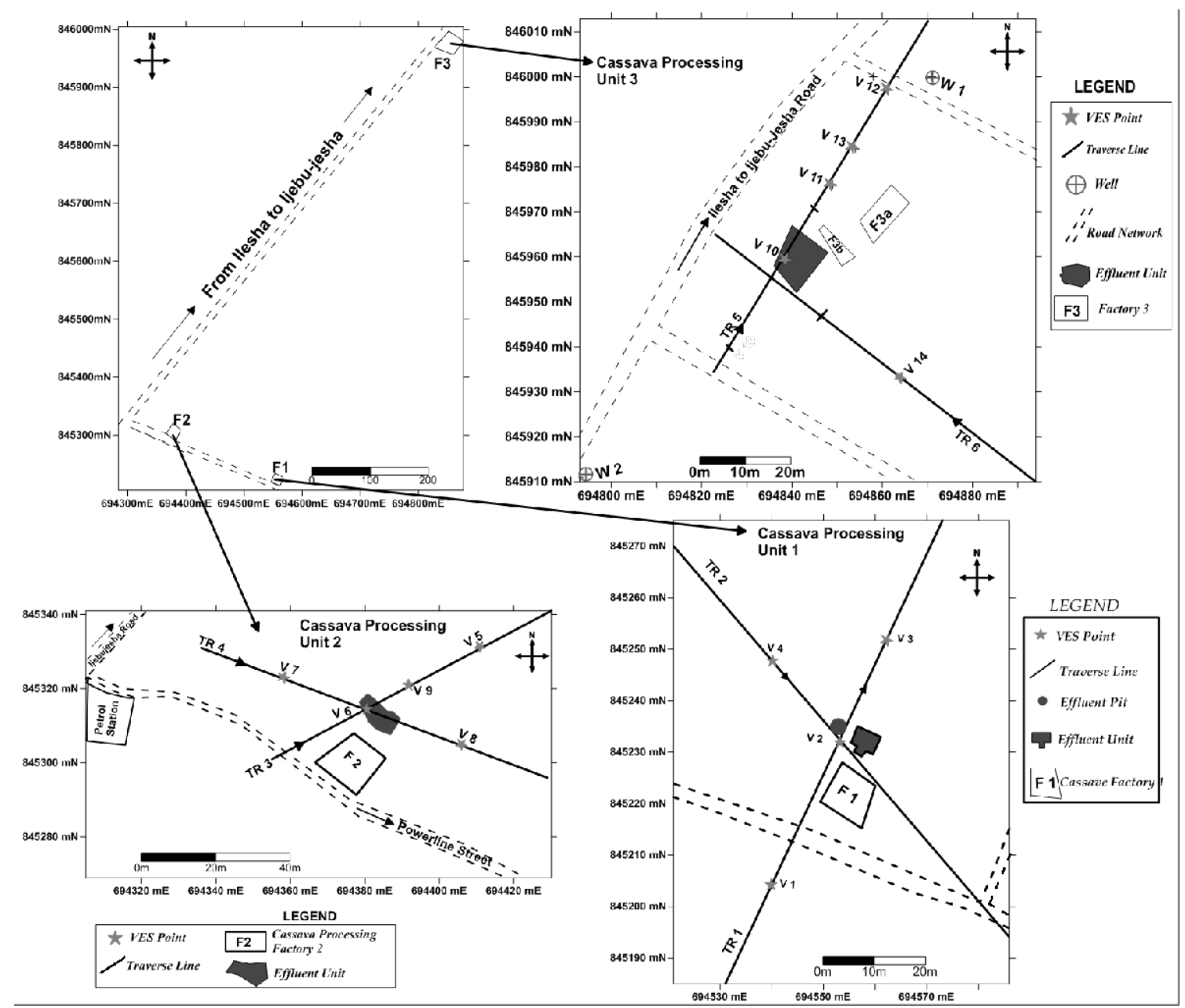

Figure 4: Map of the Study area Showing the Geophysical Traverses, VES Points and Well Locations.

\section{Geoelectric Sections}

Geoelectric Section along Traverse 1 (At Site 1)

This section relates VES 1, 2, and 3 (Fig. 5a). The topsoil resistivity values range from $162-498 \Omega \mathrm{m}$ while the thickness ranges from $0.9-1.8 \mathrm{~m}$. The lateritic layer constitutes the second layer with much higher resistivity values which range from $1369-1904 \Omega \mathrm{m}$ and thicknesses varying from 1.4 $-12.2 \mathrm{~m}$. The third layer is the weathered layer having resistivity values ranging from $236-785$ ohm- $\mathrm{m}$ and thicknesses of between $21.6-35.0 \mathrm{~m}$. The fresh basement has resistivity values ranging from $1096-5944 \Omega \mathrm{m}$. The depth to the basement bedrock ranges from $23.9-48.3 \mathrm{~m}$.

\section{Geoelectric Section along Traverse 2 (At Site 1)}

This section relates VES 4 and 2 (Fig. 5a). The topsoil resistivity values range from $162-535 \Omega \mathrm{m}$ while the thickness ranges from $1.0-1.8 \mathrm{~m}$. The lateritic layer constitutes the second layer with a higher resistivity range of $1904-2093 \Omega \mathrm{m}$ and thicknesses varying from $5.4-11.5 \mathrm{~m}$.

The third layer is the weathered layer having resistivity values ranging from $382-1004 \mathrm{ohm}-\mathrm{m}$ and thicknesses of between $35.0-47.5 \mathrm{~m}$. The basement bedrock has resistivity values range from $5944-20883 \Omega \mathrm{m}$. The depth to the basement bedrock ranges from $48.3-53.9 \mathrm{~m}$. 
Adigun and Olorunfemi: Integrated Geophysical and Hydrochemical Investigations of Subsoil

Table 1: Summary of VES Interpretation Result and their Lithologic Unit Classification

\begin{tabular}{|c|c|c|c|c|c|c|}
\hline VES & Curve Type & Layer & Thickness (m) & Depth $(\mathrm{m})$ & $-n$ & Lithologic Units \\
\hline \multirow[t]{4}{*}{1} & $\mathrm{KH}$ & 1 & 1.0 & 1.0 & 489 & Topsoil \\
\hline & & 2 & 12.2 & 13.2 & 1369 & Laterite \\
\hline & & 3 & 25.2 & 38.3 & 785 & Weathered Layer \\
\hline & & 4 & - & - & 3733 & Fresh Basement \\
\hline \multirow[t]{4}{*}{2} & $\mathrm{KH}$ & 1 & 1.8 & 1.8 & 162 & Topsoil \\
\hline & & 2 & 11.5 & 13.3 & 1904 & Laterite \\
\hline & & 3 & 35.0 & 48.3 & 382 & Weathered Layer \\
\hline & & 4 & - & - & 5944 & Fresh Basement \\
\hline \multirow[t]{4}{*}{3} & $\mathrm{KH}$ & 1 & 0.9 & 0.9 & 498 & Topsoil \\
\hline & & 2 & 1.4 & 2.3 & 1397 & Laterite \\
\hline & & 3 & 21.6 & 23.9 & 236 & Weathered Layer \\
\hline & & 4 & - & - & 1096 & Fresh Basement \\
\hline \multirow[t]{4}{*}{4} & $\mathrm{KH}$ & 1 & 1.0 & 1.0 & 535 & Topsoil \\
\hline & & 2 & 5.4 & 6.4 & 2093 & Laterite \\
\hline & & 3 & 47.5 & 53.9 & 1004 & Weathered Layer \\
\hline & & 4 & - & - & 20883 & Fresh Basement \\
\hline \multirow[t]{4}{*}{5} & $\mathrm{KH}$ & 1 & 1.0 & 1.0 & 101 & Topsoil \\
\hline & & 2 & 1.7 & 2.7 & 1739 & Laterite \\
\hline & & 3 & 3.2 & 5.9 & 289 & Weathered layer \\
\hline & & 4 & - & - & 1181 & Fresh Basement \\
\hline \multirow[t]{4}{*}{6} & $\mathrm{KH}$ & 1 & 1.0 & 1.0 & 8 & Topsoil * \\
\hline & & 2 & 0.8 & 1.8 & 450 & Laterite \\
\hline & & 3 & 4.2 & 6.0 & 32 & Weathered Layer \\
\hline & & 4 & - & - & 437 & Fresh Basement \\
\hline \multirow[t]{6}{*}{7} & KHKH & 1 & 1.0 & 1.0 & 517 & Topsoil \\
\hline & & 2 & 1.6 & 2.6 & 1163 & Laterite \\
\hline & & 3 & 2.7 & 5.3 & 282 & Weathered Layer \\
\hline & & 4 & 1.6 & 6.9 & 4574 & Fresh Basement \\
\hline & & 5 & 9.5 & 16.4 & 400 & Fractured Basement \\
\hline & & 6 & - & - & 6035 & Fresh Basement \\
\hline \multirow[t]{4}{*}{8} & $\mathrm{KH}$ & 1 & 0.9 & 0.9 & 84 & Topsoil \\
\hline & & 2 & 1.0 & 1.9 & 1707 & Laterite \\
\hline & & 3 & 4.3 & 6.3 & 990 & Weathered Layer \\
\hline & & 4 & - & - & 1400 & Fresh Basement \\
\hline \multirow[t]{5}{*}{9} & $\mathrm{HKH}$ & 1 & 0.7 & 0.7 & 113 & Topsoil \\
\hline & & 2 & 0.7 & 1.4 & 82 & Clay \\
\hline & & 3 & 1.0 & 2.4 & 2468 & Laterite \\
\hline & & 4 & 4.7 & 7.1 & 162 & Weathered Layer \\
\hline & & 5 & - & - & 1480 & Fresh Basement \\
\hline \multirow[t]{4}{*}{10} & $\mathrm{KH}$ & 1 & 0.3 & 0.3 & 95 & Topsoil \\
\hline & & 2 & 8.7 & 9.0 & 393 & Laterite \\
\hline & & 3 & 16.0 & 25.0 & 244 & Weathered Layer \\
\hline & & 4 & - & - & 9830 & Fresh Basement \\
\hline \multirow[t]{4}{*}{11} & $\mathrm{KH}$ & 1 & 1.9 & 1.9 & 229 & Topsoil \\
\hline & & 2 & 2.7 & 4.6 & 665 & Laterite \\
\hline & & 3 & 13.7 & 18.2 & 299 & Weathered Layer \\
\hline & & 4 & - & - & 790 & Fresh Basement \\
\hline \multirow[t]{4}{*}{12} & $\mathrm{KH}$ & 1 & 1.0 & 1.0 & 211 & Topsoil \\
\hline & & 2 & 2.6 & 3.6 & 615 & Laterite \\
\hline & & 3 & 13.5 & 17.0 & 45 & Weathered Layer \\
\hline & & 4 & - & - & 536 & Fresh Basement \\
\hline \multirow[t]{6}{*}{13} & KHKH & 1 & 0.7 & 0.7 & 231 & Topsoil \\
\hline & & 2 & 0.7 & 1.5 & 500 & Laterite \\
\hline & & 3 & 1.6 & 3.1 & 278 & Laterite \\
\hline & & 4 & 4.3 & 7.4 & 501 & Laterite \\
\hline & & 5 & 12.9 & 20.3 & 132 & Weathered Layer \\
\hline & & 6 & - & - & 721 & Fresh Basement \\
\hline \multirow[t]{5}{*}{14} & $\mathrm{HKH}$ & 1 & 0.8 & 0.8 & 638 & Topsoil \\
\hline & & 2 & 1.4 & 2.1 & 350 & Clay \\
\hline & & 3 & 5.5 & 7.6 & 936 & Laterite \\
\hline & & 4 & 14.1 & 21.8 & 428 & Weathered Layer \\
\hline & & 5 & - & - & 4939 & Fresh Basement \\
\hline
\end{tabular}



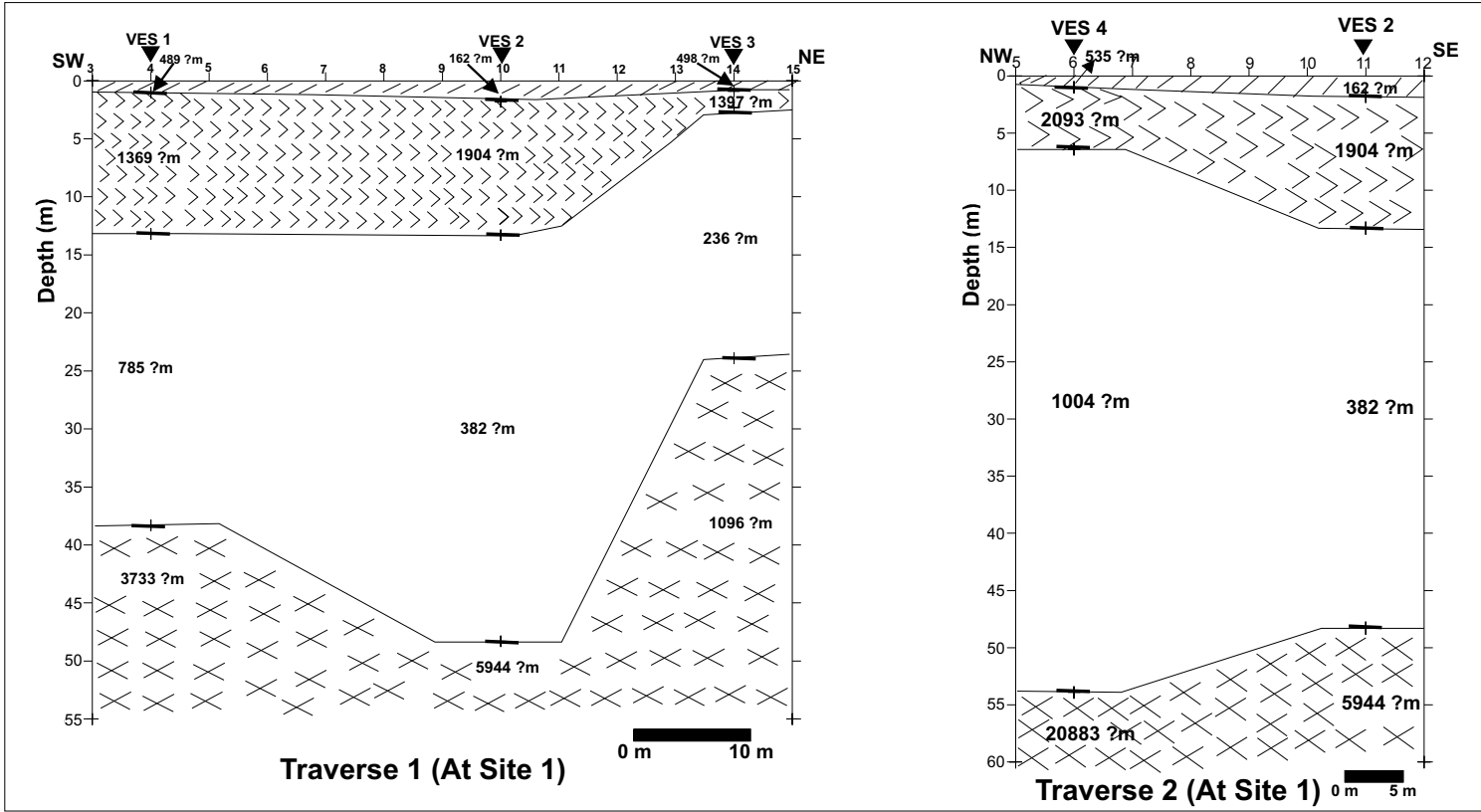

Figs. 5a: Geoelectric Sections along Traverses 1 and 2 at the Cassava Processing Site 1

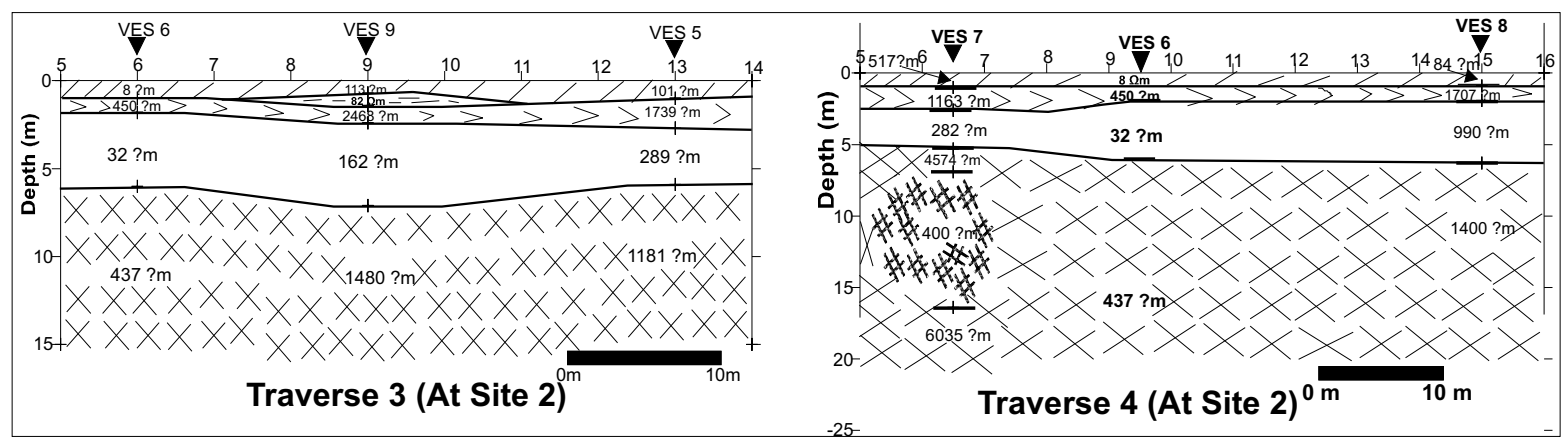

Figs. 5b: Geoelectric Sections along Traverses 3 and 4 at the Cassava Processing Site 2

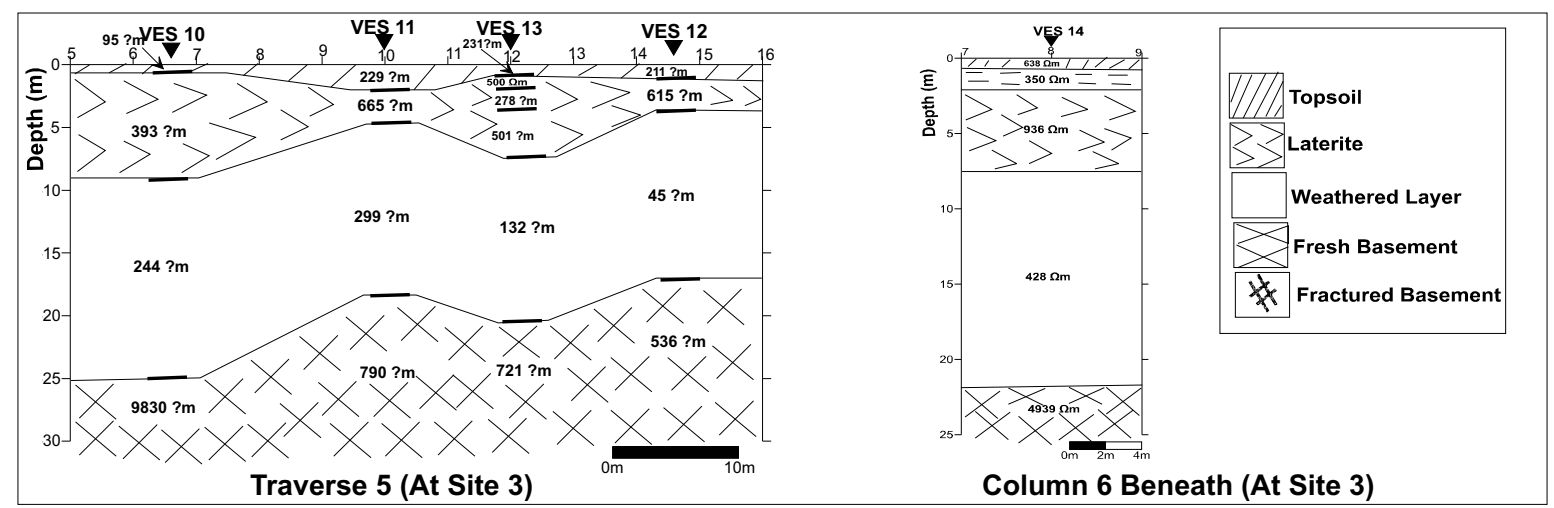

Figs. 5c: Geoelectric Sections along Traverse 5 and Beneath VES 14 along Traverse 6 at the Cassava Processing Site 3 
Geoelectric Section along Traverse 3 (At Site 2)

This section relates VES 6, 9 and 5 (Fig. 5b). The topsoil resistivity values range from $8-113 \Omega \mathrm{m}$ while the thickness ranges from $0.7-1.4 \mathrm{~m}$. The lateritic layer constitutes the second layer with higher resistivity values of $450-2468 \Omega \mathrm{m}$ and thicknesses varying from $0.8-1.7 \mathrm{~m}$. The weathered layer resistivity values range from $32-$ $289 \Omega \mathrm{m}$ with thicknesses of between 3.2 and 4.7 $\mathrm{m}$. The basement bedrock has resistivity values ranging from $437-1480 \Omega \mathrm{m}$. The depth to the basement bedrock ranges from $5.9-7.1 \mathrm{~m}$.

Geoelectric Section along Traverse 4(At Site 2) This section relates VES 7, 6 and 8 (Fig. 5b). The topsoil resistivity values range from $8-517 \Omega \mathrm{m}$ while the thickness ranges from $0.9-1.0 \mathrm{~m}$. The lateritic layer constitutes the second layer with higher resistivity values of $450-1707 \Omega \mathrm{m}$ and thickness varying from $0.8-1.6 \mathrm{~m}$. The third layer is the weathered layer having resistivity values ranging from $32-990 \Omega \mathrm{m}$ and thicknesses of between $2.7-4.3 \mathrm{~m}$. The basement bedrock has resistivity values ranging from $437-6035 \Omega \mathrm{m}$. The basement bedrock is fractured beneath VES 7 with resistivity value of $400 \Omega \mathrm{m}$ and thickness of $9.5 \mathrm{~m}$. The depth to the basement bedrock ranges from $5.3-6.3 \mathrm{~m}$.

\section{Geoelectric Section along Traverse 5 (At Site 3)}

This section relates VES 10, 11, 13 and 12 (Fig. $5 c)$. The topsoil resistivity values range from $95-$ $231 \Omega \mathrm{m}$ while the thickness ranges from $0.3-1.9$ $\mathrm{m}$. The lateritic layer constitutes the second layer with a resistivity range of $393-665 \Omega \mathrm{m}$ and thicknesses varying from $2.6-8.7 \mathrm{~m}$. The weathered layer resistivity values range from $45-$ $299 \Omega \mathrm{m}$ with thicknesses of between 12.9 and $16.0 \mathrm{~m}$. The basement bedrock has resistivity values ranging from $536-9830 \Omega \mathrm{m}$. The depth to the basement bedrock ranges from $17.0-25.0 \mathrm{~m}$.

\section{Geoelectric Section along Traverse 6 (At Site 3)}

This section (Fig. 5c) shows the subsoil sequence beneath VES 14. The topsoil resistivity values vary from $350-638 \Omega \mathrm{m}$ while the thickness is $2.2 \mathrm{~m}$.
The lateritic second layer has a higher resistivity value of $936 \Omega \mathrm{m}$ and thickness of $5.5 \mathrm{~m}$. The third layer is the weathered layer having resistivity value of $428 \Omega \mathrm{m}$ and thickness of $14.1 \mathrm{~m}$. The basement bedrock has resistivity value of 4939 $\Omega \mathrm{m}$. The depth to the basement bedrock is $21.8 \mathrm{~m}$.

\section{2-D Dipole-Dipole Images at Site 1}

\section{2-D Resistivity Image beneath Traverse 1}

The 2-D resistivity structure beneath Traverse 1 (Figs. 4d \&6a) images the upper $15 \mathrm{~m}$ of the subsurface sequence. The topsoil (in green/yellow/brownish red colour) has variable resistivity values of between 264 and $2000 \Omega \mathrm{m}$ and thicknesses too thin $(<1 \mathrm{~m})$ to be differentiated from the underlying layer (Fig. 6a). The second layer (in brownish red/purple colour) corresponds to the lateritic layer with resistivity values ranging from 358 - $5771 \Omega \mathrm{m}$ and thicknesses ranging from $4 \mathrm{~m}$ to greater than $15 \mathrm{~m}$. The third layer (in yellowish/green colour) corresponds to the weathered layer with resistivity values ranging from $102-509 \Omega \mathrm{m}$. The cassava effluent-impacted zone has not been clearly imaged by the resistivity structure. If any, the effect of the effluent may have been very limited.

\section{2-D Resistivity Image beneath Traverse 2}

The 2-D resistivity structure beneath Traverse 2 (Figs. 4d \&6b) images the upper $15 \mathrm{~m}$ of the subsurface sequence. The topsoil (in blue/green/brownish colour) has variable resistivity values ranging from 100 to $1884 \Omega \mathrm{m}$ and thicknesses of $<1.0 \mathrm{~m}$. The second layer (in green/brownish red/purple colour) corresponds to the lateritic layer with resistivity values ranging from 351 - $16887 \Omega m$ (the zone with extremely high resistivity values lies directly beneath the cassava processing centre) with thicknesses greater than $15 \mathrm{~m}$. The third layer (in green colour) corresponds to the weathered layer with resistivity values ranging from $391-1298 \Omega \mathrm{m}$. The structure images the cassava effluent-impacted zone between stations 9.5 and 12 (in blue colour) with relatively low resistivity values ranging from 94 to $220 \Omega \mathrm{m}$ and depth extent of maximum of about $2.5 \mathrm{~m}$. 


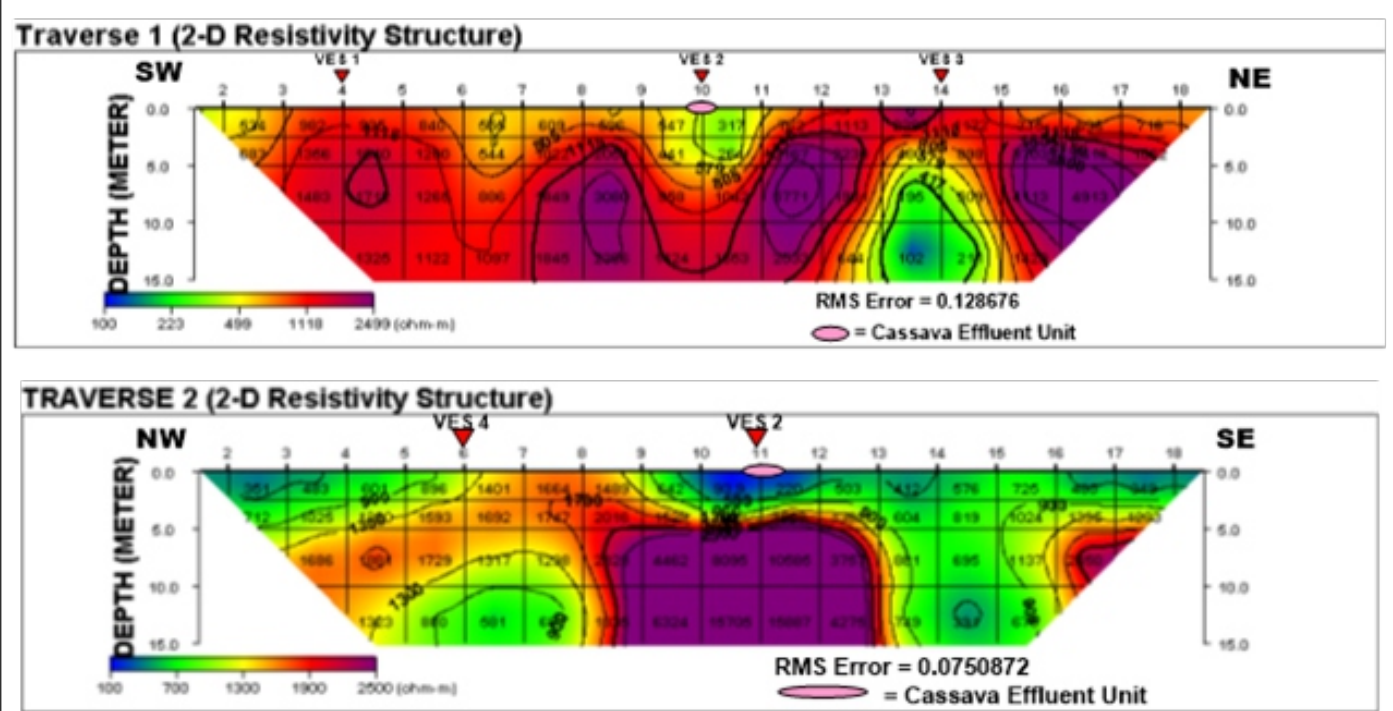

\section{Traverse 3 (2-D Resistivity Structure)}

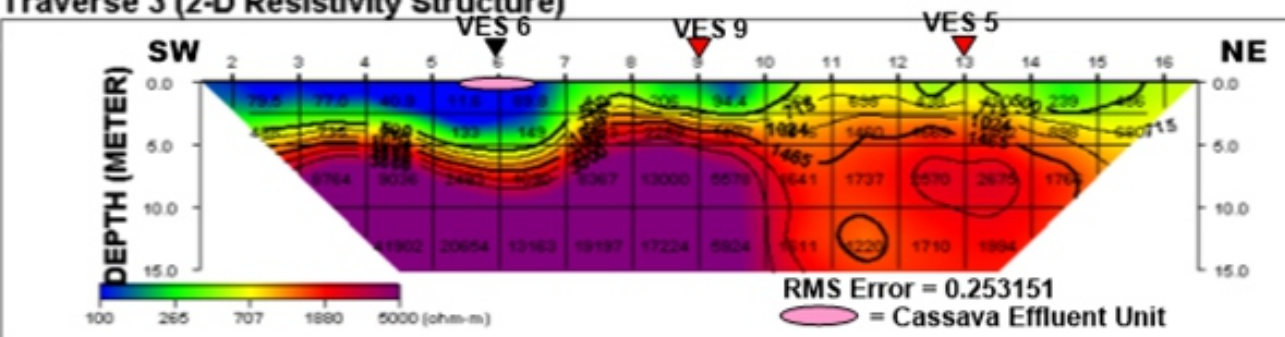

\section{Traverse 4 (2-D Resistivity Structure)}
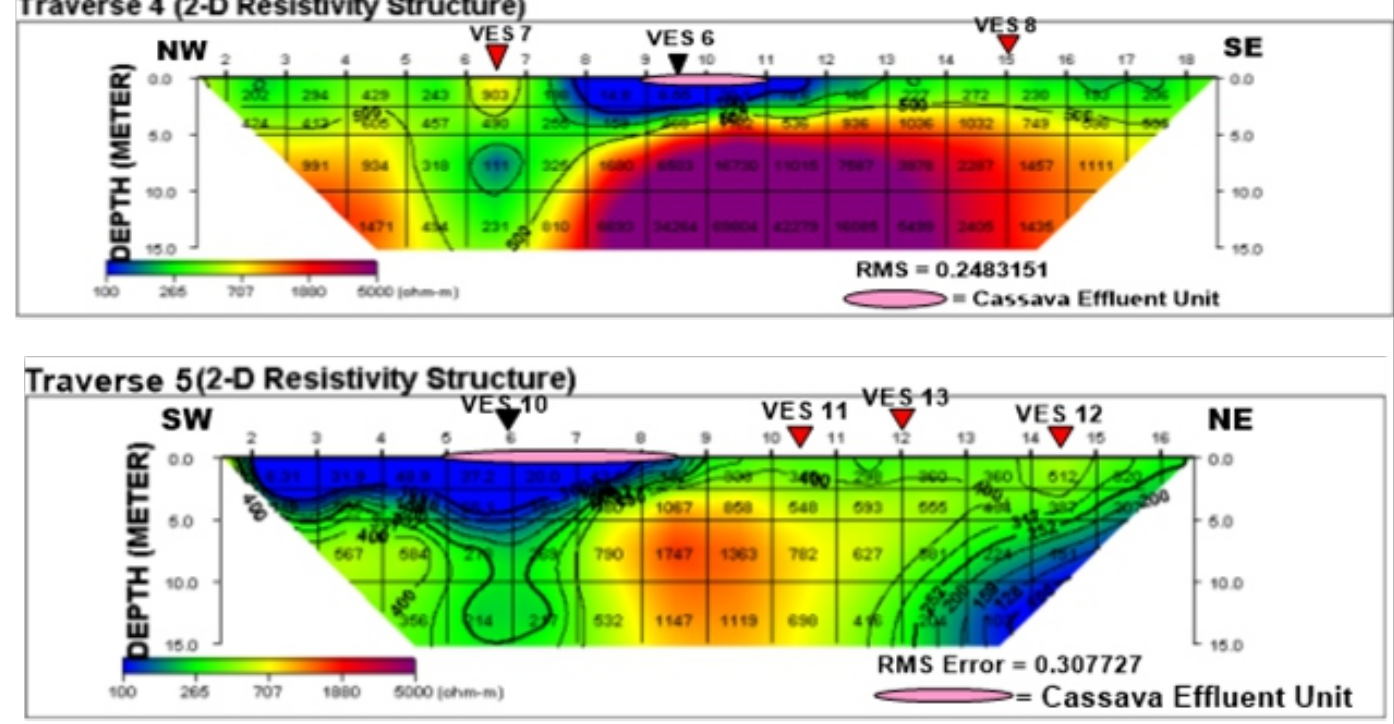

\section{Traverse 6 (2-D Resistivity Structure)}

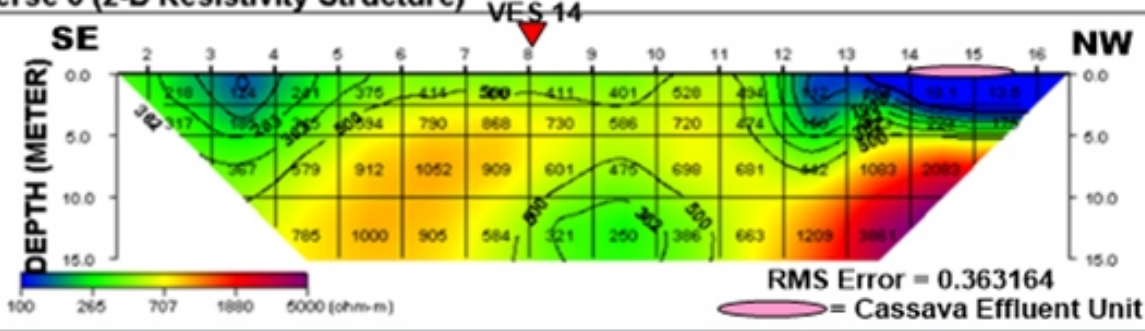

Fig 6: 2-D Resistivity Structure along Traverses 1, 2, 3, 4, 5, and 6 


\section{2-D Dipole-Dipole Images at Site 2}

\section{2-D Resistivity Image beneath Traverse 3}

The 2-D resistivity structure beneath Traverse 3 (Figs. 4c \& 6c) images the upper $15 \mathrm{~m}$ of the subsurface sequence. The topsoil (in blue/green colour) has variable resistivity values ranging from 94 to $466 \Omega \mathrm{m}$ and thickness of $<2.5 \mathrm{~m}$. The resistivity values of the second layer (laterite) appear to have merged with that of the third layer (weathered layer). The lateritic/weathered layer (in green/ yellow colour) resistivity values range from $133-898 \Omega \mathrm{m}$ and with a combined thickness ranging from $2-5 \mathrm{~m}$. The forth layer (in red/purple colour) corresponds to the fresh basement with resistivity values ranging from 1460 - $20654 \Omega \mathrm{m}$. The structure images the cassava effluent-impacted zone (in blue colour) as relatively low resistivity zone $(12-90 \Omega \mathrm{m})$ with the first boundary at station 7 and the second boundary beyond station 0 . The depth extent of the suspected impacted zone ranges from $2.0-3.5$ m.

\section{2-D Resistivity Image beneath Traverse 4}

The 2-D resistivity structure images the upper 15 $m$ of the subsurface sequence (Figs. $4 c \& 6 d$ ). The topsoil (in blue/green colour) has resistivity values ranging from 15 to $505 \Omega \mathrm{m}$ and thickness of $<1.0$ $\mathrm{m}$. The resistivity values of the second layer (laterite) appear to have merged with that of the third layer (weathered layer). The lateritic/weathered layer (green/yellow colour) resistivity values range from $457-1036 \Omega \mathrm{m}$ with thickness ranging from 2 to $6 \mathrm{~m}$. The forth layer (in red/ purple colour) corresponds to the fresh basement with resistivity values ranging from 991 - $69804 \Omega \mathrm{m}$. The structure images the cassava effluent-impacted zone (in blue colour) as relatively low resistivity zone $(7-79 \Omega \mathrm{m})$ between stations 7.5 and 12.5 . The depth extent of the suspected impacted zone ranges from $2.0-4.0 \mathrm{~m}$.

\section{2-D Dipole-Dipole Images at Site 3}

\section{2-D Resistivity Image Beneath Traverse 5}

The 2-D resistivity structure images the upper 15 $\mathrm{m}$ of the subsurface sequence (Figs.4b \& 6e). The topsoil (in blue/green colour) has variable resistivity values ranging from 6 to $593 \Omega \mathrm{m}$ and thicknesses of $<2.0 \mathrm{~m}$. The resistivity of the second layer (laterite) seems to have merged with that of the third layer (weathered layer). The lateritic/weathered layer (in green/yellow/red colour) has resistivity values ranging from 100 $1747 \Omega \mathrm{m}$ and a combined thickness of up to $12 \mathrm{~m}$. The structure images the cassava effluent pollution plume (in blue colour) as a relatively low resistivity zone $(6-68 \Omega \mathrm{m})$ between stations 1.5 and 8.5. The depth extent of the impacted zone ranges from $2.0-6.0 \mathrm{~m}$.

\section{2-D Resistivity Image beneath Traverse 6}

The 2-D resistivity structure images the upper 15 $\mathrm{m}$ of the subsurface sequence (Figs. $4 \mathrm{~b} \& 6 \mathrm{f}$ ). The topsoil (in blue/green colour) has variable resistivity values ranging from 124 to $494 \Omega \mathrm{m}$ and thicknesses of $<3.0 \mathrm{~m}$. The second layer (in yellow/red colour) corresponds to the lateritic layer with resistivity values ranging from 500 $3861 \Omega \mathrm{m}$ and thickness ranging from $5-13 \mathrm{~m}$. The third layer (in green colour) corresponds to the weathered layer with resistivity values ranging from $250-500 \Omega \mathrm{m}$. The structure images the cassava effluent pollution plume (in blue colour) as a relatively low resistive zone (14 -112 $\Omega \mathrm{m})$ which begins from station 12 and extends beyond station 16. The depth extent of the plume ranges from $2.0-4.0 \mathrm{~m}$.

\section{Hydrochemical Analysis Result}

The results of the geochemical analyses (Table 2) were compared with the World Health Organization (WHO) drinking water standards (2006). The well waters are slightly acidic (pH: 6.52-6.85) but within WHO (2006) maximum permissible level of $6.5-9.5 \mathrm{pH}$ range while the cassava effluent is very acidic with $\mathrm{pH}$ value of 4.2. For both well waters, the physico-chemical parameters are below WHO (2006) highest desirable/maximum permissible levels (see Table 2 ), indicating the waters are unpolluted and potable. However, the cassava effluent, apart from being very acidic has relatively high conductivity of $1540 \mu \mathrm{s} / \mathrm{Cm}$ (or relatively low resistivity of about $6.5 \Omega \mathrm{m}$ ) and contains $0.8 \mathrm{mg} / \mathrm{L}$ of cyanide and relatively high TDS of $924 \mathrm{mg} / \mathrm{L}$ which makes the effluent toxic. 
Table 2: Hydrochemical Analysis Result of the Cassava Effluent and the Two Well Water Samples collected at the Cassava Processing Unit 3; and the WHO Drinking Water Standards (2006)

\begin{tabular}{|c|c|c|c|c|c|c|}
\hline \multirow[b]{2}{*}{$\begin{array}{l}\mathrm{S} / \\
\mathrm{N}\end{array}$} & \multirow[b]{2}{*}{$\begin{array}{l}\text { Physicochemical } \\
\text { Parameters }\end{array}$} & \multirow{2}{*}{$\begin{array}{l}\text { Cassava } \\
\text { Effluent } \\
694840 \mathrm{mE} \\
845960 \mathrm{mN} \\
383 \mathrm{~m}\end{array}$} & \multirow{2}{*}{$\begin{array}{l}\begin{array}{l}\text { Downstream } \\
\text { Well (W2) }\end{array} \\
694793 \mathrm{mE} \\
845911 \mathrm{mN} \\
381 \mathrm{~m}\end{array}$} & \multirow{2}{*}{$\begin{array}{l}\begin{array}{l}\text { Upstream Well } \\
\text { (W1) }\end{array} \\
694871 \mathrm{mE} \\
846000 \mathrm{mN} \\
386 \mathrm{~m}\end{array}$} & \multicolumn{2}{|c|}{$\begin{array}{l}\text { WHO Drinking Water } \\
\text { Standards (2006) }\end{array}$} \\
\hline & & & & & $\begin{array}{l}\text { Highest } \\
\text { Desirable } \\
\text { Level }\end{array}$ & $\begin{array}{l}\text { Maximum } \\
\text { Permissible } \\
\text { Level }\end{array}$ \\
\hline 1 & Temperature, ${ }^{\circ} \mathrm{C}$ & 26.9 & 27.4 & 26.8 & & \\
\hline 2 & $\mathrm{pH}$ & 4.2 & 6.85 & 6.52 & $7.0-8.5$ & $6.5-9.5$ \\
\hline 3 & TDS, mg/L & 924 & 18.0 & 4.5 & 500 & 1000 \\
\hline 4 & Electrical Conductivity, $\mu \mathrm{S} / \mathrm{cm}$ & 1540 & 31.3 & 7.48 & & 1480 \\
\hline 5 & Cyanide, $\mathrm{mg} / \mathrm{L}$ & 0.8 & ND & ND & & 0.07 \\
\hline 6 & Total Hardness, mg/L & & 72.6 & 80.7 & 100 & 200 \\
\hline 7 & Carbonate $\left(\mathrm{CaCO}_{3}\right), \mathrm{mg} / \mathrm{L}$ & & 0.07 & 0.02 & 100 & 500 \\
\hline 8 & Acidity, $\mathrm{mg} / \mathrm{L}$ & & 0.1 & 0.6 & & \\
\hline 9 & Alkalinity, $\mathrm{mg} / \mathrm{L}$ & & 0.8 & 0.1 & 100 & \\
\hline 10 & Calcium $\left(\mathrm{Ca}^{2+}\right), \mathrm{mg} / \mathrm{L}$ & & 58.80 & 1.10 & 75 & 200 \\
\hline 11 & Magnesium $\left(\mathrm{Mg}^{2+}\right), \mathrm{mg} / \mathrm{L}$ & & 1.94 & 0.85 & 50 & 150 \\
\hline 12 & Sodium $\left(\mathrm{Na}^{+}\right), \mathrm{mg} / \mathrm{L}$ & & 3.40 & 1.60 & 175 & 200 \\
\hline 13 & Potassium $\left(\mathrm{K}^{+}\right), \mathrm{mg} / \mathrm{L}$ & & 4.88 & 0.53 & 13.48 & 100 \\
\hline 14 & Iron $\left(\mathrm{Fe}^{2+}\right), \mathrm{mg} / \mathrm{L}$ & & 0.14 & 0.10 & 0.3 & 1.0 \\
\hline 15 & Chloride $(\mathrm{Cl}), \mathrm{mg} / \mathrm{L}$ & & 17.80 & 27.60 & 200 & 600 \\
\hline 16 & Manganese $\left(\mathrm{Mn}^{2+}\right), \mathrm{mg} / \mathrm{L}$ & & ND & ND & 0.05 & 0.5 \\
\hline 17 & Nitrate $\left(\mathrm{NO}_{3}^{-}\right), \mathrm{mg} / \mathrm{L}$ & & 0.2 & 0.5 & 45 & 50 \\
\hline 18 & Sulphate $\left(\mathrm{SO}_{4}{ }^{2-}\right), \mathrm{mg} / \mathrm{L}$ & & 1.2 & 1.5 & 200 & 400 \\
\hline 19 & Phosphate $\left(\mathrm{PO}_{4}^{3-}\right), \mathrm{mg} / \mathrm{L}$ & & 0.3 & 0.4 & 50 & \\
\hline
\end{tabular}

ND $=$ Not Detected

\section{DISCUSSION OF RESULTS}

An electrical conductivity value of $1540 \mu \mathrm{Scm}$ ${ }^{1}$ was obtained for raw cassava effluent sample. This value corresponds to a low resistivity value of 6.5 $\Omega \mathrm{m}$ suggesting that a cassava effluent impacted soil/subsoil should display anomalously low resistivity values.

The geoelectric sections revealed that the topsoil beneath VES stations directly located on cassavaeffluent dumping units have relatively low resistivity values (162 $\Omega \mathrm{m}$ beneath VES 2 at site 1 (Fig. 5a); $8 \Omega \mathrm{m}$ beneath VES 6 at site 2 (Fig. 5b); and $95 \Omega$ m beneath VES 10 at site 3 (Fig. 5 c)).

The 2-D resistivity structures (Figs. 6a - f) also confirm that the topsoil and the underlying lateritic layer at zones beneath and around the cassava-effluent dumping sites (in pink colour) down to depth of about $6 \mathrm{~m}$ are characterised by anomalously low resistivity values $(12-90 \Omega \mathrm{m}$ beneath Traverse 3 (Fig. 6c); 7 - $79 \Omega \mathrm{m}$ beneath Traverse 4 (Fig. 6d); 6 - $68 \Omega \mathrm{m}$ beneath Traverse 5 (Fig. 6e); and $14-112 \Omega$ m beneath Traverse 6 (Fig. 6f)).
The lateral and vertical migration of the pollution plumes in the soil/subsoil along the six (6) traverses was revealed by the 2-D resistivity images (Figs. $6 \mathrm{a}-\mathrm{f}$ ). At the Cassava Processing Factory Site 1 (1 year old), the suspected pollution plume along Traverse 1 (Fig. 6a) is between stations 9.3 and 11.3 (about $10 \mathrm{~m}$ ). However along Traverse 2 (Fig. 6b), the delineated suspected impacted zone is between stations 9.5 and 12.5 with a maximum depth extent of about $2.5 \mathrm{~m}$. The pollution plume has a maximum width extent of $10 \mathrm{~m}$ at this Site. At the Processing Site 2 (13 years old), the pollution plume along Traverse 3 (Fig. 6c) has its first boundary at station 7 , and may have migrated beyond station $0(>35 \mathrm{~m})$ towards the southwestern direction. The maximum depth extent of the plume is about $3.0 \mathrm{~m}$. The pollution plume along Traverse 4 (Fig. 6d) is between stations 7.5 and 12.5 with a maximum depth extent of about $3.0 \mathrm{~m}$. The pollution plume has a maximum width extent of $27 \mathrm{~m}$ at this Site.

At the Processing Site 3 (established 20 years ago), the pollution plume along Traverse 5 (Fig. 6e) has its boundaries at stations 8.5 and 1.5 (about $35 \mathrm{~m}$ ) with a depth extent of up to $6 \mathrm{~m}$. Beneath Traverse 
6 (Fig. 6f). The pollution plume has one of its boundaries at station 12, but has extended beyond station $18(>30 \mathrm{~m})$ (Fig. 4.13) with a depth extent of up to $4.0 \mathrm{~m}$. The pollution plume has a maximum width extent of $35 \mathrm{~m}$ at this Site.

It was however revealed by the geoelectric sections (Figs. 5a-c) and 2-D resistivity structures (Figs. 6a $-\mathrm{f}$ ) beneath the six (6) traverses that the topsoil in the study area is generally underlain by thick layer of laterite which is up to about $12.2 \mathrm{~m}$ thick at some locations. This thick impervious lateritic layer (which is characterised by low permeability) has the capacity to impede the downward migration of the pollution plumes and could explain the reason why the hydrochemical analysis conducted on water samples collected from two wells located within the vicinity of the oldest cassava processing site (one at the upstream direction with Static Water Level of $9.5 \mathrm{~m}$ and the other at the downstream direction with Static Water Level (SWL) of $7.0 \mathrm{~m}$ ) show no traces of groundwater contamination. This is an indication that water from all other wells in the community will also be safe for drinking as at the time of the investigation.

The ages of the three cassava processing factories (Table 3) were plotted against the mean depth extents of the pollution plumes (Fig. 7) and empirical relationship (Eq. 1) was established. The equation shows that the depth extents of the pollution plume increases with increasing age of factories.

$\mathrm{Y}=6.4286 \mathrm{X}-11.167$

Where $\mathrm{Y}$ is Age of Factories and $\mathrm{X}$ is Depth Extent.

However, the depth migration rate of $2.5 \mathrm{~m}$ per year (Table3) at the cassava processing site 1 ( one year old) seems much higher than expected and may have been influenced by the effluent pit that was dug at the site (Fig. 4d). The depth migration rates of $0.23 \mathrm{~m} /$ year and $0.25 \mathrm{~m} /$ year of the pollution plumes at processing sites 2 and 3 are more realistic. A regression line fitted through data from sites 2 and 3 gives a linear equation:
$\mathrm{Y}=4.0882 \mathrm{X}$

with a correlation coefficient, $\mathrm{R}=0.998$ and an intercept at the origin. This is more realistic since at age 0 pollution depth extent should also be 0 .

If an average SWL of $8.25 \mathrm{~m}$ below the ground level is assumed within the vicinity of the factory site 3 (established 20 years ago), with an average migration rate of $0.24 \mathrm{~m} /$ year, it will take about 34 years (from the inception of the factory) using equation 2, for the cassava effluent pollution plume to reach the level of the Static Water Level and pollute the groundwater. This explains the reason why the groundwater in the vicinity of the cassava processing units has not been polluted.

\section{CONCLUSION}

Integrated geophysical and hydrochemical investigations were carried out within the vicinity of three cassava processing factory sites at IretiAyo Community in Ilesha, Southwestern Nigeria as a means of assessing the impact of the cassava effluent on the soil/subsoil and the groundwater quality within the study area. The results of the geoelectric investigation indicate that the topsoil at and around the cassava effluent dumping units within the vicinity of the three cassava processing factory sites has relatively low resistivity values $(6-$ $112 \Omega \mathrm{m})$ diagnostic of the cassava effluent impacted zones. The cassava effluent is characterized by relatively low resistivity value $(6.5$ $\Omega \mathrm{m})$. The pollution plumes have depth extents that range from $2.5 \mathrm{~m}$ to $5 \mathrm{~m}$. This depth extent may have been limited by the relatively thick (up to $12.2 \mathrm{~m}$ ) column of low permeability laterite which may have acted as a natural filter. The estimated migration rate is about $0.24 \mathrm{~m} /$ year.

All the physicochemical parameters of the two analyzed well water samples are below the WHO maximum permissible standards for drinking water, indicating that the groundwater within the study area has not been polluted by the effluent generated by the cassava processing activities. However, the subsoils up to depth of about $5 \mathrm{~m}$ have been polluted by the cassava effluent. 
Table 3: Estimated Depth Extents of Cassava Effluent Plume at the three Processing Factory Sites.

\begin{tabular}{|c|c|c|c|c|c|}
\hline \multirow[t]{2}{*}{ Factory } & \multirow{2}{*}{$\begin{array}{l}\text { Factory } \\
\text { Age } \\
\text { (year) }\end{array}$} & \multirow[t]{2}{*}{ Traverse } & \multicolumn{2}{|c|}{ Pollution Plume Depth Extent (m) } & \multirow{2}{*}{$\begin{array}{l}\text { Depth Migration Rate Per } \\
\text { Site (m/year) }\end{array}$} \\
\hline & & & $\begin{array}{l}\text { Depth Extent Per } \\
\text { Traverse }(\mathrm{m})\end{array}$ & $\begin{array}{l}\text { Mean Depth Extent } \\
\text { Per Site }(\mathrm{m})\end{array}$ & \\
\hline \multirow[t]{2}{*}{1} & \multirow[t]{2}{*}{1} & 1 & - & \multirow[b]{2}{*}{2.5} & \multirow[b]{2}{*}{$2.5 *$} \\
\hline & & 2 & 2.5 & & \\
\hline \multirow[t]{2}{*}{2} & \multirow[t]{2}{*}{13} & 3 & 3 & \multirow[b]{2}{*}{3} & \multirow[b]{2}{*}{0.23} \\
\hline & & 4 & 3 & & \\
\hline \multirow[t]{2}{*}{3} & \multirow[t]{2}{*}{20} & 5 & 6 & \multirow[b]{2}{*}{5} & \multirow[b]{2}{*}{0.25} \\
\hline & & 6 & 4 & & \\
\hline
\end{tabular}

*: Abnormal Migration Rate

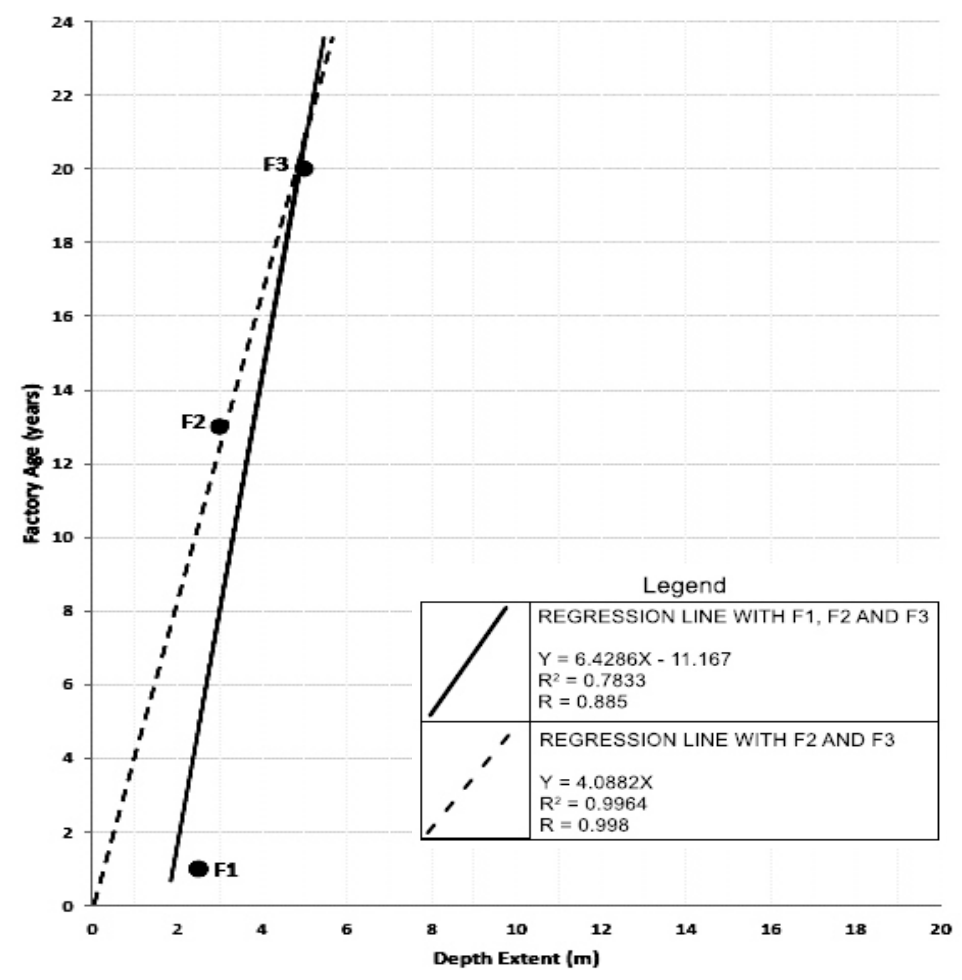

Fig. 7: Graph of the Factory Ages (year) Against the Pollution Plume Depth Extent (m)

\section{REFERENCES}

Akoteyon, I.S.; Mbata, U.A. and Olalude, E.A. 2011. Investigation of heavy metal contamination in groundwater around landfill site in a typical sub-urban settlement in Aimosho, Lagos, Nigeria. Journal of Applied Sciences in Environmental Sanitation 6(2), 155-163

Amidu,S. A. and Olayinka, A. I. 2006. Environmental Assessment of Sewage Disposal System using 2D Electrical Resistivity Imaging and Geochemical Analysis. A case study of Ibadan,
Southwestern Nigeria. Environ. Eng. Geosci. 12, 261-272.

Atakpo, E.A.; Akpoborie, A. and Ayolabi, E. 2011.

Evaluation of aquifer contamination using 2D geoelectrical imaging at Ikeja, Lagos, Nigeria. Journal of Environmental Hydrology 19(19), 1-8

Awomeso, J. A.; Taiwo, A. M.; Gbadebo, A.; and Adenowo, J. A. 2010. Pollution of water body by textile industry effluents in Lagos, Nigeria. J. Appl. Sci.Env. Sanitation 5(4), 353-359.

Bayowa, O. G.; Falebita, D. E.; Olorunfemi, M. O. and Adepelumi, A. A. 2012. Groundwater 
contamination prediction using finite element derived geoelectrical parameters constrained by chemical analysis around a sewage site, southwestern Nigeria. International Journal of Geosciences 3, 404409.

Buchanan, T. J. 1983. International Water Technology Conference and Exposition (AUGA EXPO 83) Acapulco, Mexico. pp. 67.

Federal Republic of Nigeria 2002. National water supply and sanitation policy (1st Ed.).Federal Ministry of Water Resources, Abria, Nigeria 7-11.

Felix, A. O. and Olusola, O. F. 2016. Domestic water supply sources and distribution issues in Ilesha West Local Council, Osun State, Nigeria. International Journal of Civil Engineering and Technology, 7 (3), 407-418.

Forster, C. F.; Quek, S. Y. and Wase, D. A. 1998. The use of Sago waste for the sorption of $\mathrm{Pb}$ and $\mathrm{Cu}$. Water SA4(3), 251.

Odeyemi, I. B. 1993. A Comparative Study of Remote Sensing Images of the Structureof the Okemesi Fold Belt, Nigeria. ITCJ., 1931(1), 77-81.
Olarewaju, V. O., Olorunfemi, M. O. and Alade, O. 1997. Chemical characteristics of groundwater from some parts of the basement complex of central Nigeria. Journal of Mining and Geology 33(2), 135139.

Orakwe, L. O. 2016. Environmental, physiochemical and hydrogeophysical investigation of a wetland dumpsite in Lagos State, Nigeria. Unpublished PhD Thesis, Obafemi Awolowo University, IleIfe. 165pp

Osun State Agricultural Development Programme (OSSADEP, 1997) The report of 1996 crop area and yield survey.Planning, Monitoring and Evaluation Department, Osun State Press, Osogbo, Nigeria. pp. 11.

Todd, D. K. 1980. Groundwater Hydrology. 2nd Edition, Wiley \& Sons, New York.

World Health Organisation 2006. International drinking water standards. Third edition, Geneva, Switzerland, WHO, pp. 9. 